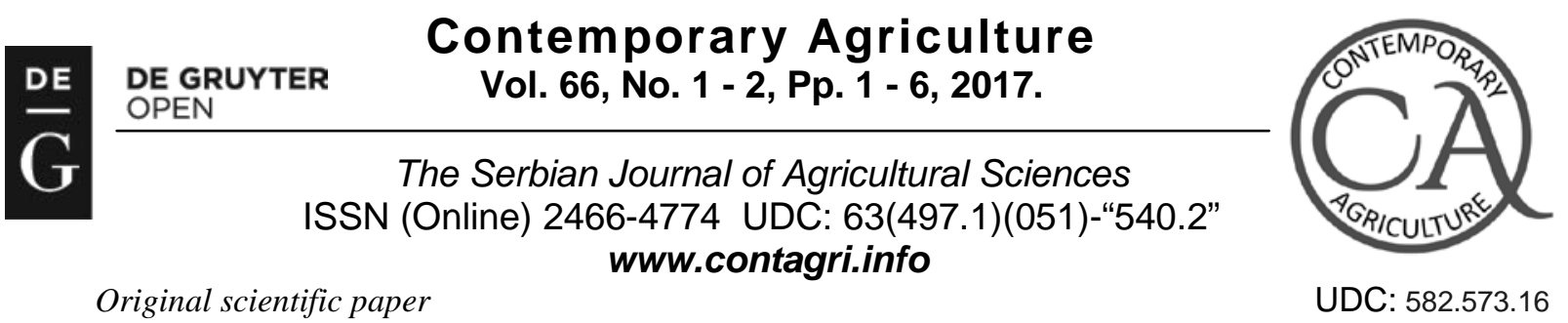

Original scientific paper

DOI:10.1515/contagri-2017-0001

\title{
ASSESSING SELECTION PARAMETERS FOR IMPROVING YIELD IN ORGANICALLY GROWN ONION
}

\author{
Milka BRDAR-JOKANOVIĆ* , Milan UGRINOVIĆ, Branka LJEVNAIĆ-MAŠIĆ, Anamarija \\ STOJANOVIĆ, Jasmina ZDRAVKOVIĆ ${ }^{1}$
}

\begin{abstract}
Summary: An increasing interest in organically grown vegetables has led to an increasing demand to select cultivars meeting the requirements of the production system. This two-year field study was undertaken to assess the effects of organic and conventional nutrient regimes on onion (Allium cepa L.) yield and several yield contributing characters, as well as to identify the traits that could be important when selecting genotypes attended for different production systems. The trial involved five commercially grown onion cultivars and four nutrient regimes: bacterial fertilizer, fully decomposed farmyard manure, without fertilization (organic) and NPK fertilization (conventional). Onion yield, bulb weight, number of bulbs plot ${ }^{-1}$, number of days from sowing to emergence, vegetation period, plant height, neck diameter, neck length, bulb diameter, bulb height and bulb index have been analyzed. Significant differences concerning all analyzed traits have been found among the cultivars, treatments and years, with significant corresponding interactions. The obtained results imply the specific adaptation to the particular treatments and weather conditions and therefore the possibility to select onion cultivars performing well in organic environments. Path coefficient analysis revealed positive direct effects of bulb weight and number of bulbs plot ${ }^{-1}$ on yield, as well as negative direct effects of plant height and number of days from sowing to emergence; therefore, those traits should be considered when selecting genotypes attended for different production systems. Other traits affected yield indirectly, mostly positively via bulb weight.
\end{abstract}

Key words: onion, organic agriculture, path coefficient analysis, yield.

\section{INTRODUCTION}

Thanks to its unique flavor, health-giving properties and ability to enhance the flavor of other foods, onion (Allium cepa L.) is one of the oldest cultivated and most widely produced vegetables. It is the second most important horticultural crop, accounting for around 10\% of world's vegetable production and following only tomato (Griffiths et al., 2002; Mallor et al., 2011).

In addition to onion traits traditionally important to agronomists, distributers and consumers (e.g. yield, bulb color and shape, storage quality, chemical composition), growing the vegetable in organic conditions has been adopted as one of the parameters determining the success of its distribution. Despite of the fact that scientific studies comparing nutritional and storage quality of conventionally and organically grown crops revealed the differences in terms of species, cultivars, the substances analyzed, the organic amendments applied and growing seasons; consumers often consider organic vegetables as higher quality alternative to the conventional ones (Faller and Fialho, 2009;Herencia et al., 2011; Ünlü et al., 2011; Maggio et al., 2013).

However, organic agriculture still relies upon cultivars bred for conventional production systems, which may be one of the reasons for comparatively low yields obtained in organic environments. Since the cultivars traditionally grown in conventionally maintained systems have been developed under high input conditions, they do not necessarily satisfy all the requirements of organic agriculture (enhanced nutrient use efficiency, competitive ability against weeds, disease tolerance). Therefore, the increasing interest in organically produced vegetables leads to an

\footnotetext{
${ }^{1}$ Milka Brdar-Jokanović, PhD, Senior Research Associate, Anamarija Stojanović, PhD, Research Associate, Institute of Field and Vegetable Crops, Maksima Gorkog 30, 21000 Novi Sad, Serbia; Milan Ugrinović, PhD, Research Associate,Jasmina Zdravković, $\mathrm{PhD}$, Principal Research Fellow, Institute for Vegetable Crops, Karađorđeva 71, 11420 Smederevska Palanka, Serbia; Branka Ljevnaić-Mašić, PhD, Associate Professor, University of Novi Sad, Faculty of Agriculture, Trg Dositeja Obradovića 8, 21000 Novi Sad, Serbia.

*Corresponding author: Milka Brdar-Jokanović, e-mail: milka.brdar@nsseme.com, phone: +381 21780365.

*This article results from the project TR 31059, supported by Ministry of Education, Science and Technological Development of Republic of Serbia.
} 
increasing demand to select cultivars meeting the requirements of this farming system (Kristensen and Ericson, 2008; Vlachostergios and Roupakias, 2008; Wolfe et al., 2008; Reid et al., 2009; 2011).

The first step in breeding cultivars attended for organic production systems is screening the available material (widely grown modern and old cultivars, local populations) in organic environments, as well as comparing their performance with the performance observed in conventional environments. Numerous studies confirmed the effect of different nutrient regimes on important onion traits, such as postharvest attributes (Kumar et al., 2007), all in content (Bloem et al., 2004), growth and mineral content (Kane et al., 2006), pungency and yield (Guo et al., 2006). Examining winter garlic rust (Puccinia spp.) rate, Vlajić et al. (2015) noted the difference in the sensitivity of the certain genotypes when grown in conventional and organic field. Furthermore, the analysis performed by Džigurski et al. (2013) implied the specificity even in weed flora occurring in organically grown onion. Therefore, besides for screening onion yield, the knowledge on the differences between conventional and organic environments in terms of the onion traits potentially affecting yield may be of considerable value for breeders.

This study was undertaken in order to assess the effects of organic and conventional nutrient regimes on several onion traits. The second aim was to identify the traits that could be important when selecting genotypes attended for different production systems.

\section{MATERIAL AND METHODS}

The two-year (2009 and 2010 onion growing seasons) trial has been conducted at the experimental field of

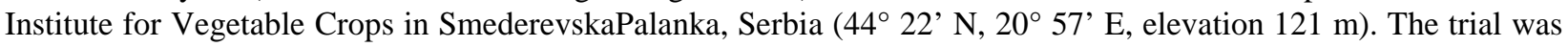
complete randomized block designed, with three replications. The main plot consisted of 3 rows, $5 \mathrm{~m}$ long. Insiderow and between-row spacing was $10 \mathrm{~cm}$ and $20 \mathrm{~cm}$, respectively. The soil type was vertisol. Sowing was performed during the period that is optimal for the region $\left(23^{\text {rd }}\right.$ and $25^{\text {th }}$ March for growing seasons of 2009 and 2010, respectively), and harvesting when $50 \%$ of plants fall over of the canopy ( $15^{\text {th }}$ July and $8^{\text {th }}$ August). Meteorological data for the two seasons are collected from the nearby station. When compared to long-term average, the seasons were characterized by higher temperatures and precipitation sums: sum of temperature was 2128.0, 2170.8 and $1946.0^{\circ} \mathrm{C}$, average daily temperature $17.4,17.8$ and $15.9^{\circ} \mathrm{C}$, while sum of precipitation was 305.0, 304.7 and 258.0 $\mathrm{mm}$ for 2009, 2010 onion growing seasons and long-term average, respectively.

The trial included five commercially grown onion cultivars (Jasenički crveni, Jasenički žuti, Majski srebrnjak, Holandski žuti and Zlatno gnezdo), two controls (NPK fertilized and unfertilized plots) and two treatments (bacterial fertilizer and fully decomposed farmyard manure). NPK fertilizer (15\% N, 15\% $\mathrm{P}_{2} \mathrm{O}_{5}$ and $15 \% \mathrm{~K}_{2} \mathrm{O}$ ) and manure were applied prior to sowing. Rates were $500 \mathrm{~kg} \mathrm{ha}^{-1}$ and $45 \mathrm{t} \mathrm{ha}^{-1}$, which is a common practice in the region. Bacterial fertilizer (Bacillus megaterium, Bacillus licheniformis, Bacillus suptilis, Azotobacterchrocoocum, Azotobactervinelandi, Derxia sp.) was applied foliar, twice during the each season, at the three-leaf stage of onion development. Conventionally maintained plots (NPK) were treated with commonly used pesticides, while no such preparation was applied to the organically maintained plots (unfertilized, bacterial fertilizer, manure). Hand-weeding was performed several times during the growing seasons in order to keep organic plots free from weeds. All plots were irrigated as needed.

Plant height $(\mathrm{cm})$, neck diameter $(\mathrm{cm})$ and neck length $(\mathrm{cm})$ were measured prior to maturity, whereas bulb weight $(\mathrm{g})$, number of bulbs plot ${ }^{-1}$, bulb diameter $(\mathrm{cm})$, bulb height $(\mathrm{cm})$ and yield $\left(\mathrm{kg} \mathrm{plot}^{-1}\right)$ were determined after harvest. Bulb index was calculated as the ratio of bulb height and diameter. Emergence (number of days from sowing to emergence) and vegetation period (number of days from emergence to maturity) were recorded during vegetation. The samples included 30 randomly selected plants per plot.

The data was processed by ANOVA, using LSD-test for comparison of means. Path coefficient analysis (Edwards, 1979) was performed in order to investigate direct and indirect effects of the traits of agronomic importance (independent variables) on yield (dependent variable) in onion grown under conventional and organic nutrient regimes. STATISTICA 12.0 software (StatSoft, Dell Inc., USA; University of Novi Sad License) was used for the calculations.

\section{RESULTS AND DISCUSSION}

The results of the factorial analysis of variance indicated statistically significant differences among the analyzed onion cultivars, growing seasons and employed fertilizer treatments, with respect to all the investigated traits. Cultivar/year, cultivar/treatment, year/treatment and cultivar/year/treatment interactions were also significant, with the exception of cultivar/year/treatment interaction for number of bulbs plot $^{-1}$ and vegetation period (not shown). The obtained results imply the specific adaptation of the analyzed onion cultivars to the particular fertilizer treatments and weather conditions; therefore, there might be a possibility to select onion cultivars adapted to organic 
environments. Significant effects of different fertilizer regimes on onion yield and yield contributing characters have been also reported by other authors (Qasem, 2006; Kumar et al., 2007).

On the average of five onion cultivars studied, the highest differences among the employed fertilizer regimes were noted for yield; ranking between 6.34 and $1.47 \mathrm{~kg} \mathrm{plot}^{-1}$ for NPK fertilized and unfertilized plots, respectively. No statistically significant difference was found between the yields obtained from unfertilized and plots fertilized with farmyard manure, which was in accordance to the results of Mirzaei et al. (2007) for garlic. On the contrary, Yassen and Khalid (2009) reported that the onion plants grown on plots fertilized with manure (farmyard, chicken and their different combinations) over yielded the plants treated with the recommended NPK doses. In addition, the application of bacterial fertilizer in our trial doubled the yield when compared to manure fertilized and unfertilized plots; however, this meant only $50 \%$ of the yield obtained from NPK fertilized plots. Similarly, Lammerts von Bueren et al. (2012) reported that the commercial organically grown onion in Netherlands reaches only $50-60 \%$ of the yield obtained in conventional production, mainly due to the downy mildew infestation and comparatively low nitrogen input. Therefore, further investigations are required to assess the organic nutrient regime that is equally or more effective than the conventional one. As for the yield components, the differences among the treatments were more pronounced for bulb weight than for number of bulbs plot ${ }^{-1}$. The mentioned relations, with particular reference to cultivar differences, are discussed in details in Brdar-Jokanović et al. (2011).

Table 1. The effect of mineral and organic fertilizers on onion traits of agronomic importance

\begin{tabular}{|c|c|c|c|c|}
\hline \multirow{2}{*}{ Onion traits } & \multicolumn{4}{|c|}{ Fertilizer treatment } \\
\cline { 2 - 5 } & NPK & Bacterial & Manure & Unfertilized \\
\hline Emergence (days) & $26.3 a$ & $27.5 b$ & $28.1 c$ & $27.7 b$ \\
\hline Vegetation period (days) & $79.5 a$ & $78.7 b$ & $78.0 c$ & $78.4 b$ \\
\hline Plant height (cm) & $60.0 a$ & $51.1 b$ & $47.8 c$ & $48.6 d$ \\
\hline Neck diameter (cm) & $1.68 a$ & $1.00 b$ & $0.91 c$ & $0.86 d$ \\
\hline Neck length (cm) & $2.77 a$ & $2.66 b$ & $2.76 a$ & $2.85 c$ \\
\hline Bulb diameter (cm) & $5.9 a$ & $4.9 b$ & $4.3 c$ & $4.2 c$ \\
\hline Bulb height (cm) & $4.4 a$ & $3.8 b$ & $3.4 c$ & $3.3 d$ \\
\hline Bulb index & $0.74 a$ & $0.75 b$ & $0.78 c$ & $0.76 d$ \\
\hline
\end{tabular}

Values within the same row followed by the same letter do not differ significantly at the 0.05 level of probability, according to LSD test

Besides for yield and its components, several traits of agronomic importance have been analyzed (Table 1). Significant differences among the treatments have been found for all the analyzed traits. Neck diameter, bulb diameter, bulb height and plant height varied the most, while the number of days from sowing to emergence, neck length and vegetation period also varied among the treatments, but not in such a wide range. Lee et al. (2014) also noted the differences between the two production systems in terms of onion growth characteristics and stressed the need for modifications in organic agricultural practices. Bulb index remained virtually the same across all nutrient regimes (flattened shape of bulbs), although the performed LSD test showed significant differences among the employed fertilizer treatments. This is an important finding since different markets have different requirements regarding onion shape and there is an interest to preserve it in both conventional and organic production systems. On the contrary, Kimani et al. (1993) reported significant variation in onion bulb shape due to seasonal variations.

The performance of the analyzed onion cultivars in terms of the traits of agronomic importance depended on the applied nutrient regime, and in the majority of the cases ranking of cultivars differed across the treatments (Table 2.). Similar changes in cultivar ranking have been reported for onion plant height (Farooq et al., 2015). On the contrary, Lammerts van Bueren et al. (2012) noted significant variety/growing system interaction, however the unchanged ranking of conventionally and organically grown onion varieties. There is a possibility that factors other than the growing system per se affect the discussed relations, such as the choice of cultivars, fertilizers and other applied measures, soil types, weather conditions. 
Table 2. Rank of the onion cultivars (JC-Jasenički crveni, JŽ-Jasenički žuti, MS-Majski srebrnjak, HŽ-Holandski žuti, ZG-Zlatno gnezdo) grown in mineral (NPK) and organic (BA-bacterial, MA-manure, UN-unfertilized) nutrient regime with respect to several traits of agronomic importance

\begin{tabular}{|c|c|c|c|c|c|c|c|c|c|c|c|c|c|c|c|c|}
\hline \multirow{2}{*}{$\begin{array}{c}\text { Onion } \\
\text { cultivar }\end{array}$} & \multicolumn{4}{|c|}{ Emergence (days) } & \multicolumn{4}{|c|}{ Vegetation period (days) } & \multicolumn{4}{|c|}{ Plant height (cm) } & \multicolumn{4}{|c|}{ Neck diameter $(\mathrm{cm})$} \\
\hline & NPK & BA & MA & UN & NPK & BA & MA & UN & NPK & BA & MA & UN & NPK & BA & MA & UN \\
\hline $\mathrm{JC}$ & 3 & 3 & 4 & 3 & 3 & 2 & 4 & 4 & 3 & 5 & 5 & 5 & 3 & 4 & 5 & 5 \\
\hline $\mathrm{JŽ}$ & 1 & 1 & 1 & 1 & 5 & 5 & 5 & 5 & 4 & 3 & 2 & 2 & 4 & 3 & 2 & 2 \\
\hline MS & 5 & 5 & 5 & 5 & 1 & 1 & 1 & 1 & 2 & 2 & 1 & 1 & 1 & 2 & 1 & 1 \\
\hline $\mathrm{HŽ}$ & 2 & 2 & 2 & 2 & 4 & 4 & 3 & 2 & 5 & 4 & 3 & 4 & 5 & 4 & 3 & 4 \\
\hline ZG & 4 & 4 & 3 & 4 & 2 & 3 & 2 & 3 & 1 & 1 & 4 & 3 & 2 & 1 & 4 & 3 \\
\hline Range & \multicolumn{4}{|c|}{$22.8-31.7$} & \multicolumn{4}{|c|}{$75.2-82.0$} & \multicolumn{4}{|c|}{$43.3-64.7$} & \multicolumn{4}{|c|}{$0.8-1.4$} \\
\hline \multirow{2}{*}{$\begin{array}{c}\text { Onion } \\
\text { cultivar }\end{array}$} & \multicolumn{4}{|c|}{ Neck length $(\mathrm{cm})$} & \multicolumn{4}{|c|}{ Bulb diameter $(\mathrm{cm})$} & \multicolumn{4}{|c|}{ Bulb height $(\mathrm{cm})$} & \multicolumn{4}{|c|}{ Bulb index } \\
\hline & NPK & $\mathrm{BA}$ & MA & UN & NPK & $\mathrm{BA}$ & MA & UN & NPK & $\mathrm{BA}$ & MA & UN & NPK & $\mathrm{BA}$ & MA & UN \\
\hline $\mathrm{JC}$ & 3 & 5 & 1 & 4 & 3 & 4 & 2 & 2 & 4 & 3 & 4 & 4 & 4 & 4 & 4 & 4 \\
\hline $\mathrm{JŽ}$ & 5 & 2 & 2 & 2 & 5 & 5 & 3 & 2 & 2 & 1 & 1 & 1 & 1 & 1 & 1 & 1 \\
\hline MS & 1 & 1 & 3 & 1 & 1 & 2 & 1 & 1 & 1 & 2 & 3 & 2 & 2 & 2 & 3 & 2 \\
\hline $\mathrm{HŽ}$ & 4 & 4 & 5 & 5 & 2 & 3 & 3 & 2 & 3 & 3 & 5 & 5 & 4 & 5 & 5 & 5 \\
\hline ZG & 2 & 3 & 4 & 3 & 4 & 1 & 3 & 2 & 2 & 2 & 2 & 3 & 3 & 3 & 2 & 3 \\
\hline Range & \multicolumn{4}{|c|}{$2.5-3.0$} & \multicolumn{4}{|c|}{$4.2-6.4$} & \multicolumn{4}{|c|}{$2.8-5.0$} & \multicolumn{4}{|c|}{$0.6-1.0$} \\
\hline
\end{tabular}

1-the highest, 5-the lowest numerical value

However, the relations mentioned above are not sufficient for the estimation of direct and indirect effects of traits of agronomic importance on yield in onion grown in conventional and organic environments. Therefore, the path coefficient analysis implying the simultaneous consideration of all investigated traits was performed (Table 3). The analysis has the advantage over the widely used Pearson's correlation coefficients that allow the interpretation of the relationship only between two traits, independently of other traits analyzed. The method was used (e.g. Islam et al., 2007; Sharangi and Sahu, 2009) in the research on the relationships among onion growth parameters and yield, as the response to various conventional nutrient regimes.

Table 3. Path coefficient analysis of direct (bold) and indirect effects of bulb weight (BW), number of bulbs plot ${ }^{-1}$ (NB), number of days from sowing to emergence (EM), vegetation period (VP), plant height (PH), neck diameter (ND), neck length $(\mathrm{NL})$, bulb diameter (BD), bulb height $(\mathrm{BH})$ and bulb index $(\mathrm{BI})$ in conventionally and organically grown onion

\begin{tabular}{|c|c|c|c|c|c|c|c|c|c|c|c|}
\hline Trait & BW & NB & EM & VP & PH & ND & NL & BD & BH & BI & $\boldsymbol{r}(\mathbf{Y})$ \\
\hline BW & $\mathbf{1 . 1 4}^{* *}$ & 0.13 & 0.05 & -0.00 & -0.28 & -0.04 & 0.00 & -0.02 & 0.00 & -0.00 & $0.98^{* *}$ \\
\hline NB & 0.86 & $\mathbf{0 . 1 7}^{* *}$ & 0.08 & -0.00 & -0.24 & -0.03 & 0.00 & -0.02 & 0.00 & 0.02 & $0.82^{* *}$ \\
\hline EM & -0.45 & -0.07 & $\mathbf{- 0 . 1 3}^{*}$ & 0.01 & 0.12 & 0.02 & 0.00 & 0.01 & 0.00 & 0.03 & $-0.46^{*}$ \\
\hline VP & 0.15 & 0.04 & 0.08 & $-\mathbf{0 . 0 1}$ & -0.06 & -0.00 & -0.00 & -0.00 & 0.00 & -0.00 & 0.19 \\
\hline PH & 1.08 & 0.14 & 0.05 & -0.00 & $\mathbf{- 0 . 2 9}$ & -0.04 & 0.00 & -0.02 & 0.00 & 0.01 & $0.93^{* *}$ \\
\hline ND & 1.09 & 0.13 & 0.05 & -0.00 & -0.28 & $\mathbf{- 0 . 0 4}$ & 0.00 & -0.02 & 0.00 & 0.00 & $0.94^{* *}$ \\
\hline NL & 0.10 & 0.02 & 0.05 & -0.01 & -0.05 & -0.00 & $\mathbf{- 0 . 0 0}$ & 0.00 & 0.00 & 0.03 & 0.14 \\
\hline BD & 1.10 & 0.13 & 0.06 & -0.00 & -0.26 & -0.04 & 0.00 & $\mathbf{- 0 . 0 2}$ & 0.00 & -0.02 & $0.94^{* *}$ \\
\hline BH & 0.84 & 0.13 & 0.01 & -0.00 & -0.23 & -0.03 & 0.00 & -0.02 & $\mathbf{0 . 0 0}$ & 0.06 & $0.76^{* *}$ \\
\hline BI & -0.05 & 0.03 & -0.04 & 0.00 & -0.04 & 0.00 & -0.00 & 0.01 & 0.00 & $\mathbf{0 . 0 9}$ & 0.00 \\
\hline
\end{tabular}

$\mathrm{R}_{\mathrm{y}}{ }^{2}=0.9835$

$r(\mathrm{Y})$ - correlation with yield

The great majority of the analyzed onion traits correlated positively to yield. The only negative correlation was noted for number of days from sowing to emergence, while no statistically significant correlation was calculated between yield and vegetation period, neck length and bulb index.

However, significant direct positive effects on yield were exhibited only by yield components (bulb weight and number of bulbs plot $^{-1}$ ), while other traits affected yield indirectly, mostly positively via bulb weight. Similar results have been reported by Degewione et al. (2011) for shallot bulb weight. The highest negative direct effect on yield had plant height, despite of strong positive correlation of the two parameters. Those relations may be explained by significant positive indirect effect of plant height on yield, mostly via bulb weight. Positive relations between onion 
yield and plant height have been also reported by Islam et al. (2007). Number of days from sowing to emergence had significant negative effect on yield (both direct and indirect), suggesting the importance of early emergence for onion yield formation. Therefore; based on the results of this study, bulb weight, plant height, number of bulbs plot ${ }^{-1}$ and number of days from sowing to emergence are onion traits that should be considered when selecting cultivars attended for different production systems.

\section{CONCLUSION}

Significant differences have been found among the analyzed onion cultivars, fertilizer treatments and growing seasons in terms of yield and yield contributing characters. Cultivar/treatment, cultivar/year, treatment/year and cultivar/treatment/year interactions were also significant in almost all cases, implying the specific adaptation of the cultivars to the particular nutrient regimes and weather conditions and, consequently, the possibility to select onion cultivars adapted to organic environments. Further investigations are required to assess the organic nutrient regime that is equally or more effective than the conventional one.

When selecting genotypes attended for different production systems, attention should be paid to bulb weight, plant height, number of bulbs plot ${ }^{-1}$ and number of days from sowing to emergence.

\section{REFERENCES}

BLOEM, E., HANEKLAUS,S., SCHNUG, E.: Influence of nitrogen and sulfur fertilization on the alliin content of onions and garlic. J. Plant Nutr., 27:1827-1839, 2004.

BRDAR-JOKANOVIĆ, M., UGRINOVIĆ, M., CVIKIĆ, D., PAVLOVIĆ, N., ZDRAVKOVIĆ, J., ADŽIĆ, S., ZDRAVKOVIĆ, M.: Onion yield and yield contributing characters as affected by organic fertilizers. Field Veg. Crop Res., 48(2)341-346, 2011.

Degawione, A., Alamerew,S.,Tabor,G.: Genetic variability and association of bulb yield and related traits in shallot (Allium cepa var. aggregatum Don.). International Journal of Agricultural Research, 6:1-20, 2011.

Edwards, A.L.: Multiple regression and analysis of variance and covariance. Freeman, W.H. Comp, San Francisco, USA,pp.3138, 1979.

FAROOQ, M., SHAH, A.H., MALIK, A.A., ALI, N., KHAN, U., MAJID, A., AHMAD, H.: Nutrient management for improving onion productivity. American-Eurasian J. Agric. \& Environ. Sci., 15(2)220-225, 2015.

DŽIGURSKI, D., NIKOLIĆ, LJ., LJEVNAIĆ-MAŠIĆ, B.: Weed flora in organic onion production - Allium cepa L. (Alliaceae Borkhausen 1797, Amaryllidales). Journal on Processing and Energy in Agriculture, 17(3)130-133, 2013.

FALLER, A.L.K. AND FIALHO, E.: The antioxidant capacity and polyphenol content of organic and conventional retail vegetables after domestic cooking. Food Res. Int., 42:210-215, 2009.

GRIFFITHS, G., TRUEMAN, L., CROWTHER, T., THOMAS, B., SMITH, B.: Onions - A global benefit to health. Phytother. Res., 16:603-615, 2002.

GUO, T., ZHANG, J., CHRISTIE, P., LI, X.: Influence of nitrogen and sulfur fertilizers and inoculation with arbuscular mycorrhizal fungi on yield and pungency of spring onion. J. Plant Nutr., 29:1767-1778, 2006.

HERENCIA, J.F., GARCÍA-GALAVÍS,P.A., DORADO, J.A.R., MAQUEDA, C.: Comparison of nutritional quality of the crops grown in an organic and conventional fertilized soil. Sci. Hort., 129:882-888, 2011.

ISLAM, M.K., ALAM, M.F., ISLAM, A.K.M.R.: Growth and yield response of onion (Allium cepa L.) genotypes to different levels of fertilizers. Bangl. J. Bot., 36:33-38, 2007.

KANE, C.D., JASONI, R.L., PEFFLEY, E.P., THOMPSON, L.D., GREEN, C.J., PARE, P., TISSUE, D.: Nutrient solution and solution pH influences on onion growth and mineral content. J. Plant Nutr., 29:375-390, 2006.

KIMANI, P.M., KARIUKI, J.W., PETERS, R., RABINOWITCH, H.D.: Influence of the environment on the performance of some onion cultivars in Kenya. Afr. Crop Sci. J., 1:15-23, 1993.

KRISTENSEN, K. AND ERICSON, L.: Importance of growth characteristics for yield of barley in different growing systems: will growth characteristics describe yield differently in different growing systems? Euphytica, 163:367-380, 2008.

KUMAR, S., IMTIYAZ, M., KUMAR, A.: Effect of differential soil moisture and nutrient regimes on postharvest attributes of onion (Allium cepa L.). Sci. Hortic., 112:121-129, 2007.

LAMMERTS VAN BUEREN, E.T., OSMAN, A:M., TIEMENS-HULSCHER, M., STRUIK, P.C., BURGERS, S.L.G.E., VAN DEN BROEK, R.C.F.M.: Are specific testing protocols required for organic onion varieties? Analysis of onion variety testing under conventional and organic growing conditions.Euphytica, 184:181-193, 2012.

LEE, J., HWANG, S., LEE, S., HA, I., HWANG, H., LEE, S., KIM, J.: Comparison study on soil physical and chemical properties, plant growth, yield, and nutrient uptakes in bulb onion from organic and conventional systems. HortScience, 49(12)1563-1567, 2014.

MAGGIO, A., DE PASCALE, S., PARADISO, R., BARBIERI, G.: Quality and nutritional value of vegetables from organic and conventional farming. Sci. Hortic., 164:532-539, 2013.

MALLOR, C., BALCELLS, M., MALLOR, F., SALES, E.: Genetic variation for bulb size, soluble solids content and pungency in the Spanish sweet onion variety Fuentes de Ebro. Response to selection for low pungency. Plant Breeding, 130:55-59, 2011.

MIRZAEI, R., LIAGHATI, H., MAHDAVI DAMGHANI, A.: Evaluating yield quality and quantity of garlic as affected by different farming systems and garlic clones. Pak. J. Biol. Sci., 10:2219-2224, 2007. 
QASEM, J.R.: Response of onion (Allium cepa L.) plants to fertilizers, weed competition duration, and planting times in the central Jordan Valley. Weed Biol. Manag., 6:212-220, 2006.

REID, T.A., YANG, R.-C., SALMON, D.F., SPANER, D.: Should spring wheat breeding for organically managed systems be conducted on organically managed land? Euphytica, 169:239-252, 2009.

REID, T.A., YANG, R.-C., SALMON, D.F., NAVABI, A., SPANER, D.: Realized gains from selection for spring wheat grain yield are different in conventional and organically managed systems. Euphytica, 177:253-266, 2011.

SHARANGI, A.B., SAHU, P.K.: Effect of placement and dose of phosphatic fertilizers on onion. J. Plant Nutr., 32:1901-1913, 2009.

ÜNLÜ, H., ÖZDAMAR ÜNLÜ, H., KARAKURT, Y., PADEM, H.: Influence of organic and conventional production systems on the quality of tomatoes during storage. Afr. J. Agr. Res., 6:538-544, 2011.

VLACHOSTERGIOS, D.N. AND ROUPAKIAS, D.G.: Response to conventional and organic environment of thirty-six lentil (Lens culinaris Medik.) varieties. Euphytica, 163:449-457, 2008.

VLAJIĆ, S., GVOZDANOVIĆ-VARGA, J., STOJANOVIĆ, A., MAŠIREVIĆ, S., MEDIĆ PAP, S., TAKAČ, A.: Winter garlic rust (Puccinia spp.) rate under organic and conventional production conditions. Ratar.Povrt., 52(1)39-43, 2015.

WOLFE, M.S., BARESEL, J.P., DESCLAUX, D., GOLDRINGER, I., HOAD, S., KOVACS, G., LÖSCHENBERGER, F., MIEDANER, T., ØSTERGÅRD, H., LAMMERTS VAN BUEREN, E.T.: Developments in breeding cereals for organic agriculture. Euphytica, 163:323-346, 2008.

YASSEN, A.A. AND KHALID, KH.A.: Influence of organic fertilizers on the yield, essential oil and mineral content of onion. Int. Agrophys., 23:183-188, 2009.

\title{
SELEKCIONI PARAMETRI ZA POBOLJŠANJE PRINOSA CRNOG LUKA GAJENOG PO PRINCIPIMA ORGANSKE PROIZVODNJE
}

\author{
Milka BRDAR-JOKANOVIĆ, Milan UGRINOVIĆ, Branka LJEVNAIĆ-MAŠIĆ, Anamarija STOJANOVIĆ, Jasmina \\ ZDRAVKOVIĆ
}

Izvod: Cilj rada bio je da se ispita efekat organskih i konvencionalnog režima ishrane na prinos i svojstva koja su u vezi sa prinosom crnog luka, kao i da se identifikuju svojstva koja bi mogla biti značajna kod selekcije genotipova namenjenih za različite sisteme proizvodnje. Dvogodišnji poljski ogled je uključivao pet sorti crnog luka i četiri režima ishrane: mikrobiološko đubrivo, zgoreli stajnjak, neđubrenje (organski) i NPK đubrivo (konvencionalni). Analizirani su: prinos, masa lukovice, broj lukovica po parceli, broj dana od setve do nicanja, dužina trajanja vegetacije, visina biljke, prečnik i dužina lažnog stabla, prečnik, visina i indeks lukovice. Značajne razlike među sortama, režimima ishrane i sezonama koje su utvrđene u pogledu svih analiziranih svojstava upućuju na specifičnosti adaptacije na pojedine režime ishrane, odnosno na mogućnost selekcije sorti luka namenjenih za organsku proizvodnju. Path koeficijent analizom su utvrđeni direktni pozitivni efekti mase lukovice i broja lukovica po parceli, kao i negativni direktni efekti visine biljke i broja dana od setve do nicanja na prinos; stoga bi na ova svojstva trebalo obratiti pažnju prilikom selekcije genotipova namenjenih za različite sisteme proizvodnje. Druga proučavana svojstva su uticala na prinos indirektno, većinom pozitivno preko mase lukovice.

Ključne reči: crni luk, organska poljoprivreda, path koeficijent analiza, prinos.

\author{
Received / Primljen: 04.11.2016. \\ Accepted / Prihvaćen: 04.07.2017.
}

